\section{PRINT ISSN 1119-8362}

Electronic ISSN 1119-8362
Full-text Available Online at https://www.ajol.info/index.php/jasem http://ww.bioline.org.br/ja
J. Appl. Sci. Environ. Manage.

Vol. 24 (8) 1455-1461 August 2020

\title{
Influence of Sprouting on Proximate and Anti-nutritional Factors of Jacbean (Canavalia ensiformis) Flour
}

\author{
*1ODEDEJI, JO; ${ }^{2}$ AKANDE, EA, ${ }^{1}$ AYINDE, LA; ${ }^{2}$ ALADE, OA
}

\author{
${ }^{1}$ Osun State Polytechnic, Iree, Osun State, Nigeria. \\ ${ }^{2}$ Ladoke Akintola University of Technology, Ogbomoso, Oyo State, Nigeria. \\ *Corresponding Author Email: odedeji2014@gmail.com
}

\begin{abstract}
The influence of sprouting on proximate and anti-nutritional factors of Jackbean flour was investigated. Jackbean was procured from the Genetic Resources Unit of International Institute of Tropical Agriculture (IITA), Ibadan, Oyo State Nigeria. The seeds were carefully sorted and sprouted for 10 days. The sprouted and unprocessed (control) bean were then milled into flour and thereafter assessed for proximate and antinutritional factors. The data generated were subjected to statistical analyses using SAS 2.0 and SPSS 20.0 packages. The results of influence of sprouting on proximate constituents and anti-nutritional factors revealed that sprouting for nine days $\left(\mathrm{S}_{5}\right)$ resulted in flour sample with highest protein content and significant reduction in anti-nutritional factors most especially trypsin inhibitor from $32.08 \pm 0.13 ; 29.18 \pm 0.46$ in control to $39.50 \pm 0.06 ; 18.33 \pm 0.03$ in the sprouted samples respectively. Sprouting thus had positive effect on proximate and anti-nutritional factors of Jackbean flour.
\end{abstract}

\section{DOI: https://dx.doi.org/10.4314/jasem.v24i8.22}

Copyright: Copyright $(\subseteq 2020$ Odedeji et al. This is an open access article distributed under the Creative Commons Attribution License (CCL), which permits unrestricted use, distribution, and reproduction in any medium, provided the original work is properly cited.

Dates: Received: 30 May 2020; Revised: 03 July 2020; Accepted: 05 August 2020

Keywords: Proximate, jackbean, anti-nutritional, sprouting

Jackbean (Canavalia ensiformis) referred to as "Sese nla" in Yoruba, is amongst the tropical legumes that thrives well in Nigeria (Okonkwo and Udedibie, 1991, Odedeji, et al., 2019). Jackbean is grossly underutilized in most developing countries of the world most importantly Nigeria. This has seriously affected the maximum propagation and utilization of the crop despite its nutritional qualities. Those planting the seeds in Nigeria plant them as ornamental plants and in some places, the plant is believed to be "snake expellant" (Odedeji, et al., 2019). The legume has potential in product development and consumption, but its extensive period of processing, and tough seed coat have affected the pasting properties of the flour (Akande et al., 2013). Quality parameters of food products developed from legume flour samples generally affect the functional and pasting properties influenced by the processing conditions employed (Ezeocha and Onwuka, 2010). Various pre-processing techniques had been employed to improve the processing, nutritional quality, organoleptic acceptability, reduction in the oligosaccharides and other anti-nutritional factors. Some of the commonly used pre-processing techniques included soaking, boiling at high temperatures (in water, alkaline or acidic solutions), fermentation, autoclaving, roasting, dehulling, microwaving, steam blanching and sprouting (El-Adawy, 2002 and Skulinova et al., 2002). Sprouting of leguminous seeds improves the protein and other nutritional contents and reduces the anti-nutritional compositions (Mahando, 2004; Harper and Zandi, 2008 and Srilakshmi, 2008). Plant proteins are major sources of human's nutrition since animal protein are expensive for the poor (Owuamanam et al., 2014). Food processing operations not only improves flavour and palatability of foods but also increase the bioavailability of nutrients by inactivating some antinutritional factors and growth inhibitors (Chau et al., 1997). Studies had revealed that pre-treatments such as sprouting, soaking/fermentation, autoclaving, blanching or roasting could enhance the quality of seeds and grain products (Ade- Omowaye et al., 2003; Kirbaslar and Erkmen, 2003 and Carmelia et al., 2007). Sprouting of soybean had been reported to increase the ascorbic acid content, riboflavin and niacin (Iwe, 2003). Reported studies on the beans are majorly on its utilization in animal feed formulations (Udebibie, 1997 and Anyanwu et al., 2011). There is paucity of information on the effect of sprouting on the proximate and anti-nutritional factors of Jackbean grown in developing countries, which is responsible for its in-extensive use (Ikegwu et al., 2010). This work therefore investigated the effect of sprouting on

* Corresponding Author Email: odedeji2014@gmail.com 
the proximate and anti-nutritional factors of Jackbean flour.

\section{MATERIALS AND METHODS}

Materials: The seeds of Jackbean (Canavalia ensiformis) with Accession Number: TCe4 were collected from the Genetic Resources Unit of International Institute of Tropical Agriculture (IITA), Ibadan, Oyo State Nigeria. The seeds were cultivated at the experimental farm of Osun State Polytechnic, Iree. Chemicals (Analytical Grade) and equipment were obtained from the Department of Food Science and Engineering, Ladoke Akintola University of Technology, Ogbomoso and Department of Food Technology, Osun State Polytechnic, Iree, Osun State Nigeria.

Preparation of the beans: The fruits (pods) of Jackbean were harvested after maturity (four months) and sundried. The seeds were removed from the pod by shelling and were thereafter winnowed to remove chaff.

Production of Flour from Raw and Treated Jackbean: Matured Jackbean seeds, after four months of planting, were thoroughly cleaned and sorted to remove defective ones. The seeds were thereafter graded according to their sizes. The cleaned seeds were soaked in warm water to soften the hull and ease its removal. The hulls were removed by repeated working between the palms and were removed leaving behind dehulled seeds. The dehulled seeds were thereafter drained and dried to reduce the moisture content and facilitate grinding into flour. The modified method of Hassan et al. (2006) was used for sprouting. $200 \mathrm{~g}$ of beans were steeped in $1500 \mathrm{ml}$ of water for 24 hours at room temperature. The steeped beans were drained, each portion was allowed to malt for 1, 2, 3, 4, and 5 days respectively. The samples were wetted and turned twice daily to keep the temperature below 19 ${ }^{0} \mathrm{C}$. The samples were sprayed with $2 \%$ formaldehyde solution to prevent the growth of mold. The sprouted beans were dried in a cabinet dryer at $45 \pm 2{ }^{0} \mathrm{C}$ for $6 \mathrm{hrs}$ to moisture content of $12 \%$. The plumules were removed before processing into flour. The dried seeds were pulverized to fine particle size and sieved to obtain fine powder ( $1 \mathrm{~mm}$ mesh size) for the control sample. The flour samples were packaged using high density polyethylene material for further analytical work (Uche et al., 2014).

Effect of Sprouting on the Proximate Constituents of Jackbean
Moisture content and dry matter: The moisture content was determined using method described by No. 925.10, AOAC (1990).

The percentage moisture content and dry matter were calculated as follows:

$\%$ Dry matter $=\frac{\mathrm{w}_{2}-\mathrm{W}_{\mathrm{O}} \times 100}{\mathrm{w}_{1}-\mathrm{W}_{\mathrm{O}}}$

$\%$ Moisture content $=\frac{\left(\mathrm{W}_{2}-\left(\mathrm{W}_{3}\right) \times 100\right.}{\left(\mathrm{W}_{2}-\mathrm{W}_{1}\right)}$

$\mathrm{W}_{\mathrm{o}}=$ Weight of crucible; $\mathrm{W}_{1}=$ Weight of crucible; $\mathrm{W}_{2}$ $=$ Weight of crucible + dry sample; $\mathrm{W}_{3}=$ Weight of crucible + dry sample with constant weight.

Crude Protein: The crude protein content was determined using kjedhal method as described by AOAC, (2000)

$\% \mathrm{~N}=$

$\frac{1.401 \times\left(\mathrm{cm}^{3} \mathrm{HCI} \text { sample }-\mathrm{cm}^{3} \mathrm{HCI} \text { titre of blank }\right) \mathrm{MHCI}}{\mathrm{Sw}}$

$\%$ protein $=\% \mathrm{~N} \times 6.25 ; \mathrm{Sw}=$ Sample weight; $\mathrm{N}=$ Nitrogen

Ash Content: The ash content was determined using AOAC, (1990) method.

$$
\% \text { Ash content }=\frac{W_{2}-W_{0}}{W_{1}-W_{0}} \times 100 \%
$$

$\mathrm{W}_{0}=$ Weight of the crucible; $\mathrm{W}_{1}=$ Weight of the crucible + sample before ashing; $\mathrm{W}_{2}=$ Weight of the crucible + sample after ashing

Crude Fat: $5 \mathrm{~g}$ of the sample was measured into a set of three free thimbles after it has been dried free of moisture (AOAC, 2000) using soxhlet apparatus.

$\%$ Crude fat (ether extract) $=\frac{\mathrm{W}_{1}-\mathrm{W}_{2} \times 100 \%}{\mathrm{Sw}}$

$\mathrm{W}_{1}=$ Weight of the flask; $\mathrm{W}_{2}=$ Weight of the flask and the oil; $\mathrm{Sw}=$ Sample Weight

Crude Fibre: Crude fibre was determined through the documented method of AOAC, (2000).

$$
\% \text { Ash content }=\frac{W_{2}-W_{0}}{\mathrm{~W}_{1}-W_{0}} \times 100 \%
$$

$\mathrm{W}_{1}=$ Weight before incineration: $\mathrm{W}_{2}=$ Weight after incineration; $\mathrm{Sw}=$ Sample Weight 
Effect of Sprouting on the Anti-nutritional Factors of the Flour

Phytate content: The phytate content of the flour was determined using the modified method of Maga (1982). $2 \mathrm{~g}$ of each finely ground flour sample was soaked in $20 \mathrm{ml}$ of $0.2 \mathrm{~N} \mathrm{HCl}$ filtered, $0.5 \mathrm{ml}$ filtrate was mixed with $1 \mathrm{ml}$ Ferric ammonium sulphate solution, boiled for $30 \mathrm{~min}$, cooled in ice for $15 \mathrm{~min}$. and centrifuged for $15 \mathrm{~min}$. One milliliter of the supernatant was mixed with $1.5 \mathrm{ml}$ of 2.2 - pyridine solution and the absorbance measured in a spectrophotometer at $519 \mathrm{~nm}$.

Tannin content: Tannin content of the samples was determined using the method of Makkar and Goodchild, (1996).

Oxalate Content: Titration method described by Day and Underwood (1986) was used to determine the oxalate content.

Polyphenols Content: The total polyphenols in the sample was determined using purssion blue spectrophotometric method with tannic acid as the standard as described by Oladele et al. (2009).

Trypsin Inhibitor: The modified method of Arntified et al. (1985) was used in the determination of trypsin inhibitor which involves the use of spectrophotometer to measure the absorbance of supernatant of centrifuged mixture of $0.5 \mathrm{~g}$ of the sample with $50 \mathrm{mls}$ of $0.5 \mathrm{~m} \mathrm{NaCl}$ solution The absorbance for the control was measured. Trypsin inhibitor activity was calculated using the formula:

$$
\mathrm{TuI} / \mathrm{g}=\frac{1}{\mathrm{~W}} \times \frac{\mathrm{au}-\mathrm{as}}{0.01} \times \frac{\mathrm{vf}}{\mathrm{va}}
$$

Where: $\mathrm{w}=$ Weight of sample; $\mathrm{au}=$ Absorbance of sample at $410 \mathrm{~nm}$; as =Absorbance of control; vf = Total extract volume; $v a=$ Volume of extract analyzed

Saponin Content: The solvent extraction gravimetric method described by Nwosu, (2010) was used for the determination of saponin content of the sample.

$$
\% \text { Saponin }=\frac{\mathrm{W}_{2}-\mathrm{W}_{1}}{\mathrm{Wt} \text { of sample }} \times \frac{100}{1}
$$

Where: $\mathrm{W}_{1}=$ Weight of evaporating dish; $\mathrm{W}_{2}=$ Weight of dish of sample

Data Analysis: Data collected were subjected to analysis of variance (ANOVA) using SPSS version 20.0 and SAS 2.0 package. The means were separated by Duncan's multiple range test at 5\% level of probability, while Pearson's correlation co-efficient was also done to establish relationship among the preprocessing methods used in this research.

\section{RESULTS AND DISCUSSION}

Effect of Sprouting on Proximate Composition of Jackbean Flour: The result of influence of sprouting on proximate constituents of jackbean flour is presented in table 1 . The moisture content of sample $\mathrm{S}_{4}$ showed higher significant effect $(\mathrm{P}<0.05)$ with a mean value of $8.73 \pm 0.11$ compared to all other samples and the raw. Sample $\mathrm{S}_{1}$ displayed the least value of $8.27 \pm 0.31$ for moisture content. The values for this parameter ranged between $8.73 \pm 0.11$ and $8.27 \pm 0.31$, which fall within the acceptable limit of 0 $-13 \%$, which has been reported to be suitable for storage and processing of flours without microorganism degradation of the triglyceride (James, 1995). The moisture content of the samples were lower compared to the one reported for sprouted field bean by Myrene, (2013). There was increment in moisture content over the sprouting period until in sample $\mathrm{S}_{5}$ where there was slight reduction to $8.60 \pm 0.35$. The slight increment in moisture content over the sprouting period might be due to moisture uptake by the germinating seed as reported by Nonogaki et al., (2010). Sample $\mathrm{S}_{5}$ showed higher significant effect (P $<0.05)$ with a mean value of $39.50 \pm 0.06$ for protein compared to the raw sample. It was observed that there was sudden drop from $32.08 \pm 0.13$ in protein in the raw sample to $30.53 \pm 0.23$ in sample $S_{1}$. This quickly increased on the second day to $34.30 \pm 0.55$ and throughout the sprouting period compared to the raw sample. The highest value of $39.50 \pm 0.06$ was recorded by sample $S_{5}$. The lowest value of $33.43 \pm$ 1.22 was recorded by sample $\mathrm{S}_{4}$. The significant increase in protein content as observed in the sprouted samples might be attributed to increased water activity as a result of induction of hydrolytic enzymes (Bau et al., 1997), hormonal changes (Nonogaki et al., 2010) or a compositional change following the degradation of other constituents. Similar increase in protein content was reported for African oil bean, mungbean and Australian sweet lupin upon germination (Enujiugha et al., 2003; Mubarak, 2005; Rumiyati et al., 2012).

The fat content of raw sample displayed higher significant $(\mathrm{P}<0.05)$ effect and mean of $3.80 \pm 0.10$ compared to other pre-processed samples. It was observed that as the sprouting time was on the increase, the fat content was reducing. The value reduced from $3.60 \pm 0.20$ in sample $S_{1}$ to $3.13 \pm 0.06$ in sample $\mathrm{S}_{5}$. This might be as a result of evaporative loss during drying of the flour sample. This equally 
makes the product healthier as fat has been implicated in coronary heart disease (NSRL, 2002). The ash content, an indication of mineral content displayed higher significant effect $(\mathrm{P}<0.05)$ for the untreated sample. The ash content was on the decrease over the sprouting period. The ash content decreased from 3.52 \pm 0.03 in sample $S_{1}$ to $2.77 \pm 0.60$ in sample $S_{5}$. The values reported were higher than the value reported for field bean by Myrene, (2013). The reduction in ash content might be due to the leaching out of both macro and micro elements (Myrene, 2013). The crude fibre displayed similar significant effect $(\mathrm{P}<0.05)$ with varied mean values $5.42 \pm 0.03,5.41 \pm 0.01$ and 5.40 \pm 0.03 for samples $S_{1}, S_{2}$ and $S_{3}$ compared to the raw sample. This parameter displayed steady reduction from $5.42 \pm 0.03$ to $4.83 \pm 0.02$ over the sprouting period. The raw sample, $\mathrm{S}_{4}$ and $\mathrm{S}_{5}$ showed similar but lower significant effect for this parameter. The crude fibre value recorded were however relatively higher than the value reported for kidney bean by Audu and Aremu (2011). Sample $\mathrm{S}_{1}$ showed higher significant effect $(\mathrm{P}<0.05)$ with mean of $48.66 \pm 0.43$ for carbohydrate compared to the untreated sample. Samples $\mathrm{S}_{3}, \mathrm{~S}_{4}$ and $\mathrm{S}_{5}$ showed no significant difference for carbohydrate. The carbohydrate content was found to be reducing from $44.76 \pm 2.73$ in sample $S_{2}$ to 41.50 \pm 0.06 for sample $S_{5}$ compared to the raw sample and $\bar{S}_{1}$. The low carbohydrate and fat content due to sprouting is of dietary significance to diabetic patients, and for people suffering from cardiovascular disease and hyper-cholesterolemia (Myrene, 2013).

Effect of Sprouting on Anti-nutritional Factors of Jackbean Flour: Table 2 presents the results of the effect of sprouting on anti-nutritional factors of jackbean flour. Sprouting is partial germination of produce. It initiates three main types of chemical changes in the seed; the breakdown of certain materials, transport of materials from one part of the seed to another, especially from the endosperm to the embryo or from the cotyledons to the growing parts and finally the synthesis of new materials from the breakdown products formed (Esonu, et al., 1998; Shipard, 2005). The phenolic compound is higher in samples $S_{1}$ with a value of $2.29 \pm 0.10 \mathrm{mg} / \mathrm{kg}$ but with no significant effect $(p<0.05)$ between sample $S_{2}$ and the untreated sample with a value of $2.23 \pm 0.06$ and $2.26 \pm 0.03 \mathrm{mg} / \mathrm{kg}$ respectively. The values for this anti-nutritional factor ranged between $2.29 \pm 0.10$ and $1.86 \pm 0.02 \mathrm{mg} / \mathrm{g}$. It was noted that this anti-nutritional factor was decreasing as the sprouting day increased. Sample $\mathrm{S}_{5}$, which represented sample sprouted for 5 days after the first sign of germination, recorded the least value. The least value recorded due to sprouting is in line with the submission of Owuamanam, et al. (2014) who worked on the use of seed sprouting in modification of food nutrients and reduction of antinutrients.

Similar trend was observed for tannin but with relatively lower mean value in samples $S_{0}, S_{1}$, and $S_{2}$, showing similar significant effect $(\mathrm{p}<0.05)$ but with slightly varied tannin content of $1.00 \pm 0.02,1.02 \pm$ 0.06 and $0.99 \pm 0.03$ respectively. Sample $\mathrm{S}_{5}$ recorded the least value of $0.80 \pm 0.01$. There was steady reduction in this anti-nutritional factor as sprouting day increased, which corroborated the view of Megat and Azrina, (2012) who reported reduction in tannin content of soybean and peanut.

Table 1: Effect of Sprouting on Proximate Constituents of Jackbean Flour

\begin{tabular}{|c|c|c|c|c|c|c|}
\hline Parameters & So & $\mathbf{S}_{1}$ & $\mathbf{S}_{2}$ & $\mathbf{S}_{3}$ & $\mathbf{S}_{4}$ & $\mathbf{S}_{5}$ \\
\hline Moisture Content & $8.33+0.23^{\mathrm{d}}$ & $8.27+0.31^{\mathrm{e}}$ & $8.53 \pm 0.11^{\mathrm{c}}$ & $8.67 \pm 0.23^{\mathrm{b}}$ & $8.73 \pm 0.11^{\mathrm{a}}$ & $8.60 \pm 0.35^{\mathrm{bc}}$ \\
\hline Protein & $32.08+0.13^{\mathrm{e}}$ & $30.53+0.23 f$ & $34.30 \pm 0.55^{\mathrm{c}}$ & $37.80 \pm 1.44^{\mathrm{b}}$ & $33.43 \pm 1.22^{\mathrm{d}}$ & $39.50 \pm 0.06^{\mathrm{a}}$ \\
\hline Fat & $3.80+0.10^{\mathrm{a}}$ & $3.60+0.20^{\mathrm{ab}}$ & $3.50+0.10^{\mathrm{bc}}$ & $3.37+0.11^{\mathrm{cd}}$ & $3.27+0.03^{\mathrm{de}}$ & $3.13+0.06^{\mathrm{e}}$ \\
\hline Ash & $4.41 \pm 0.14^{\mathrm{a}}$ & $3.52 \pm 0.03^{\mathrm{b}}$ & $3.50 \pm 0.01^{\mathrm{b}}$ & $3.46 \pm 0.01^{\mathrm{b}}$ & $3.41 \pm 0.01^{\mathrm{b}}$ & $2.77 \pm 0.60^{c}$ \\
\hline Crude Fibre & $5.00 \pm 0.35^{\mathrm{b}}$ & $5.42 \pm 0.03^{\mathrm{a}}$ & $5.41 \pm 0.01^{\mathrm{a}}$ & $5.40 \pm 0.01^{\mathrm{a}}$ & $4.83 \pm 0.03^{\mathrm{b}}$ & $4.83 \pm 0.02^{\mathrm{b}}$ \\
\hline Carbohydrate & $46.38+0.41^{\mathrm{ab}}$ & $48.66+0.43^{\mathrm{a}}$ & $44.76+2.73^{b}$ & $41.27+1.72^{\mathrm{c}}$ & $41.33+1.33^{\mathrm{c}}$ & $41.50+0.06^{c}$ \\
\hline
\end{tabular}

Values are means of triplicate determinations; Means with the same superscript are not significantly different at $\mathrm{P}<0.05$ along the column; $\mathrm{S}_{0}$ $=$ Raw jackbean flour; $\mathrm{S}_{1}=$ Sprouted jackbean flour Day $5 ; \mathrm{S}_{2}=$ Sprouted jackbean flour Day $6 ; \mathrm{S}_{3}=$ Sprouted jackbean flour Day 7; $\mathrm{S}_{4}=$ Sprouted jackbean flour Day 8; $\mathrm{S}_{5}=$ Sprouted Jackbean Flour Day 9

Table 2. Effect of Sprouting on Anti-nutritional Factors of Jackbean Flour

\begin{tabular}{lllllll}
\hline Parameters & So & $\mathbf{S}_{1}$ & $\mathbf{S}_{2}$ & $\mathbf{S}_{3}$ & $\mathbf{S}_{4}$ & $\mathbf{S}_{5}$ \\
\hline Phenolic $(\mathrm{Mg} / \mathrm{g})$ & $2.26 \pm 0.03^{\mathrm{a}}$ & $2.29 \pm 0.10^{\mathrm{a}}$ & $2.23 \pm 0.06^{\mathrm{a}}$ & $1.99 \pm 0.05^{\mathrm{b}}$ & $1.93 \pm 0.07^{\mathrm{bc}}$ & $1.86 \pm 0.02^{\mathrm{c}}$ \\
Tannin $(\mathrm{Mg} / \mathrm{g})$ & $1.00 \pm 0.02^{\mathrm{a}}$ & $1.02 \pm 0.06^{\mathrm{a}}$ & $0.99 \pm 0.03^{\mathrm{a}}$ & $0.86 \pm 0.02^{\mathrm{b}}$ & $0.83 \pm 0.03^{\mathrm{bc}}$ & $0.80 \pm 0.01^{\mathrm{c}}$ \\
Phytate (Mg/g) & $0.13 \pm 0.01^{\mathrm{d}}$ & $0.23 \pm 0.03^{\mathrm{c}}$ & $0.36 \pm 0.01^{\mathrm{a}}$ & $0.29 \pm 0.03^{\mathrm{b}}$ & $0.35 \pm 0.04^{\mathrm{a}}$ & $0.22 \pm 0.03^{\mathrm{c}}$ \\
Oxalate (\%) & $0.13 \pm 0.01^{\mathrm{a}}$ & $0.11 \pm 0.01^{\mathrm{b}}$ & $0.11 \pm 0.02^{\mathrm{b}}$ & $0.10 \pm 0.01^{\mathrm{b}}$ & $0.10 \pm 0.01^{\mathrm{b}}$ & $0.09 \pm 0.01^{\mathrm{b}}$ \\
Saponin (\%) & $0.78 \pm 0.03^{\mathrm{a}}$ & $0.77 \pm 0.07^{\mathrm{a}}$ & $0.71 \pm 0.05^{\mathrm{b}}$ & $0.71 \pm 0.04^{\mathrm{b}}$ & $0.61 \pm 0.01^{\mathrm{c}}$ & $0.60 \pm 0.03^{\mathrm{c}}$ \\
Trypsin Inhibitor (\%) & $29.18 \pm 0.46^{\mathrm{a}}$ & $28.67 \pm 0.15^{\mathrm{ab}}$ & $23.46 \pm 0.07^{\mathrm{c}}$ & $23.96 \pm 0.09^{\mathrm{c}}$ & $28.23 \pm 0.53^{\mathrm{b}}$ & $18.33 \pm 0.03^{\mathrm{d}}$
\end{tabular}

Values are means of triplicate determinations; Means with the same superscript are not significantly different at $\mathrm{P}<0.05$ along the column; $\mathrm{S}_{0}=$ Raw jackbean flour; $\mathrm{S}_{1}=$ Sprouted jackbean flour Day $5 ; \mathrm{S}_{2}=$ Sprouted jackbean flour Day $6 ; \mathrm{S}_{3}=$ Sprouted jackbean flour Day 7; $\mathrm{S}_{4}=$ Sprouted jackbean flour Day $8 ; \mathrm{S}_{5}=$ Sprouted jackbean flour Day 9

ODEDEJI, JO; AKANDE, EA, AYINDE, LA ALADE, OA 
Phytate had higher significant effect and value of 0.36 \pm 0.04 in sample $S_{2}$ compared to other pre-processed sample and the raw that recorded the least value of $0.13 \pm 0.01$. Sample $\mathrm{S}_{4}$ recorded the next higher value of $0.35 \pm 0.04$ but with no significant effect with sample $\mathrm{S}_{2}$. It was observed that there was increase in phytate content over the sprouting period compared to the raw sample, a view that deviated from the finding of Megat and Azrina, (2012). The values recorded for all the samples however, were less than one. Oxalate recorded higher significant effect $(\mathrm{P}<0.05)$ and a mean value of $0.13 \pm 0.01$ for the raw sample compared to other pre-processed samples. It was observed that there was steady reduction in oxalate content as the sprouting period increased. It reduced from $0.11+$ 0.01 in sample $S_{1}$ to $0.09 \pm 0.01$ in sample $S_{5}$. This supported the findings of $\bar{M}$ egat and Azrina (2012); Owuamanam, et al. (2014). Relatively, oxalate was the least anti-nutritional factor in the sample. The saponin content was found to decrease steadily over the sprouting time. It decreased from $0.77 \pm 0.01$ in sample $S_{1}$ to $0.60 \pm 0.03$ in sample $S_{5}$. Higher and similar significant effect $(\mathrm{P}<0.05)$ was recorded for samples $S_{0}$ and $S_{1}$ but with values of $0.78 \pm 0.03$ and $0.77 \pm 0.07$ respectively. Samples $S_{2}$ and $S_{3}$ equally gave similar mean value of $0.71 \pm 0.05$ and the effect is significant. Sample $\mathrm{S}_{5}$ recorded the least value for this anti-nutritional factor but with similar significant effect with sample $\mathrm{S}_{4}$.

This reduction in saponin content supports the submission of Owuamanam et al. (2014) who work on the use of seed sprouting in modification of food nutrients and pasting profile profile of tropical legume flours. Trypsin inhibitor showed higher significant ( $P$ $<0.05$ ) effect and mean value of $29.18 \pm 0.46$ for raw sample. There was decrease in the trypsin inhibitor over the sprouting period from $28.67 \pm 0.15$ in sample $S_{1}$ to $18.33 \pm 0.03$ in sample $S_{5}$. Samples $S_{2}$ and $S_{3}$ showed no significant effect with mean values of $23.46 \pm 0.07$ and $23.96 \pm 0.09$ respectively. The reduction in trypsin inhibitor due to sprouting corroborated the submission of Owuamanam et al. (2014) report on the use of seed sprouting in modification of food nutrients and pasting profile of tropical legume flours.

Conclusion: The study revealed that sprouting of Jackbean had significant effects on proximate and anti-nutritional factors. Sprouting for nine days resulted in sample with highest protein content and greatest reduction in anti-nutritional factors. This pre- processing method therefore suggests that Jackbean could be crop of great industrial potentials, thus, its maximum propagation should be encouraged.

\section{REFERENCES}

Ade-Omowaye, BIO; Olajide, JO; Oluyomi, EO (2003). Pretreatment Sorghum-Cassava Flour as a Substitute for Traditional Nigeria Yam Flour (Elubo) Plant Foods Human Nutrition. 58, 1-11.

Akande, EA; Oladipo, AO; Kelani OS (2013). Effect of Steaming on The Physicochemical Properties and The Cooking Time of Jackbean (Canavalia ensiformis). J. Expert. Biol. Agric. Sci. 1, 6.

Anyanwu, DC; Ukaegbu, EP; Ogueri, C (2011). Nutrient Utilization and Growth Response of Clarias Ganepienus Fingerlings Fed Dietary Levels of Jackbean (Canavalia ensiformis) Meal. New York Sci. J.rnal. 4(4), 68-71.

AOAC (1990). Official Methods of Analysis. 15 Edition, Association of Official Analytical Chemist. Washington D.C.

AOAC (2000). Association of Official Analytical Chemists. Official Methods of Analysis. $17^{\text {th }}$ ed. Washington D.C. Pp. 16

Arntfield, SD; Ismopnd, MAH; Murray, ED (1985). The Fate of Anti-nutritional Factors during the Preparation of Faba Bean Protein Isolate using Micellization Techniques. Can.inst. Food Science. Inno. 18. 137 - 143.

Audu, SS; Aremu, MO (2011). Effect of Processing on Chemical Composition of Red kidney Bean (Phaseolus vugaris L.) Flour. Pak. J. Nutr. 10 (11): $1069-1075$.

Bau, HM; Nicolas, JP; Mejean, L (1997). Effect of germination on chemical composition, biochemical constituents and antinutritional factors of soybean (Glycine max) seeds. J. Sci. Agric. 73:1-9.

Carmelia, AS; Beatriz de la C; Marcel B; Richard HS; Elke A (2007). Impact of the Roasting Degree of Coffee on the in Vitro Radical Scavenging Capacity and Content of Acrylamide LWT 40 : $1849-1854$. 
Chau, CF; Cheung, PC; Wong, YS (1997). Effect of cooking on content of amino acids and antinutrients in three Chinese indigenous legume seeds. J. Sci. Food.Agric. 75, 447-452.

Day, RA (Jnr); Underwood, AL (1986). Quantitative Analysis. $5^{\text {th }}$ Ed. Prentize - Hall Publication.

El - Adawy, TA (2002). Nutritional Composition and Anti-nutritional Factors of Chickpeas (Cicer arietinum L) Undergoing Different Cooking Methods and Germination. Plant Food for Human Nutrition. 57, 83- 97.

Enujiugha, VN; Badejo, AA; Iyiola, SO; Oluwamukonci, MO (2003). Effect of Germination on the Nutritional and Functional Properties of African Oil Bean (Pentaclethra Macrophylla Benth) Seed Flour. Food Agric. Environ. 1 (3 \& 4): $72-75$.

Esonu, BO; Udedibie, ABI; Carlini, CR (1998). The Effect of Toasting, Dry Urea Treatment and Sprouting on some Thermostable Toxic Factors in the Jackbean Seed. Nig. J. Ani. Prod. 25 (1): $36-$ 39

Ezeocha, VC; Owuka, GI (2010). Effect of Processing Methods on the Physicochemical and Nutritional Quality of Maize and soybean based complementary Blends. Nig. Food J. 28 (2), 210 $-216$.

Harper, SS; Zandi, CC (2008). Effect of germination on the chemical, functional and pasting properties of legumes flours. <http:// www.sciencedirec.com/ zan-ob-real.

Hassan, AB; Ahmed, IAM; Osman, M; Eltayeb, NM; Osman, GA; Babiker, EE (2006). Effect of processing treatments followed by fermentation on protein content and digestibility of Pear millet (Pennisetum typhoideum) cultivars. Pak. J. Nutri. 5(1), 86-89.

Ikwegwu, OJ; Okechukwu, PE; Ekumankama, EO (2010). Physicochemical and Pasting Characteristics of Flour and Starch from 'Achi' Brachystegia eurycoma Seed. J. Food Tech. 8(2), $58-66$.
Iwe, MO (2003). The Science and Technology of Soybean: Chemistry, Nutrition, Processing and Utilization. Rojoint Communication Services Limited Publisher.

James, CS (1995). Analytical Chemistry of Foods.1st Edn Chapman and Hall, New York

Kirbaslar, FG; Erkmen, G (2003). Investigation of the Effect of Roasting Temperature on the Nutritive Value of Hazenuts Plant Foods. Hum Nutri. 58, 1 -10 .

Maga, JA (1982). Phytates: Its Chemistry, Occurrence, Food Interactions, Nutritional Significance and Methods of Analysis. J. Agric. Food Chem. 30 (1), 1 - 7.

Mahando, FS (2004). Functional properties of germinated legumes (Phaseolus vulgaris and Cajanus cajan) Flour. Available at: <http:// www.cababstractsplus.org/ abstract.aspx $>28$ th January, 2013.

Makkar, AOS; Goodchild, AV (1996). Qualification of Tannins. A Laboratory Manual Int. Centre for Agriculture. A Laboratory Manual Int. Centrre for Agriculture Research in the Dry Areas (ICARDA), Aleppo, Syria, I.V + 25pp.

Megat- Rusydi, MR; Azrina, A (2012). Effect of Germination on Total Phenolic, Tannin and Phytic Acid Contents in Soybean and Peanut. Inter. Food Res. J. 19 (2): 673 - 677.

Mubarak, AE (2005). Nutritional Composition and Anti-nutritional Factors of Mung Bean Seeds (Phascolus aureus) as Affected by some Home Traditional Processes. Food Chem. 89 (4): 489 495.

Myrene R D'souza (2013). Effect of Traditional Processing on Nutritional Quality of Field Bean. Adv. Biores. 4 (3), $29-33$.

Nonogaki, H; Bassel, GW; Bewley, JW (2010). Germination still a Mystery. Plant Science. 179: $574-581$.

NSRL, (2002). National Soybean Research Laboratory. A Publication of National Soybean Research Laboratory on Soybean Processing from Field to Consumer ( $<$ www/NSRL). 
Nwosu, JN (2010). Effect of Soaking, Blanching and Cooking on the Anti-nutritional Properties of Asparagus Bean (Vigna Sesquipedis) Flour. 1-5.

Odedeji, JO; Akande, EA; Fapojuwo, OO; Olawuyi, OJ (2019). Influence of roasting on nutritional and antinutritional factors of Jackbean, Canavalia ensiformis (L) D.C. flour. J. Underutilized Legumes. 1(1): $112-121$

Okonkwo, JC; Udedibie, ABI (1991). Preliminary observation on the yield performance of Jackbean (Canavalia ensiformis) and sword bean (Canavalia gladiata) in the Guinea Savannah of Nigeria. Paper presented at the $27^{\text {th }}$ Annual Conference of Agriculture of Nigeria, Mina, and Nigeria. 1 - 4 September.

Oladele, AK; Osundahunsi, OF; Adebowale, YA (2009). Effect of Processing Techniques on the Nutrients and Antinutrients Contents of Tigernut (Cypercus esculentus). Nig. Food J. 27 (2), $210-$ 218.

Owuamanam, C; Ogueke, C; Iwouno, J; Edom, T (2014). Use of Seed Sprouting in Modification of Food Nutrients and Pasting Profile of Tropical Legume Flours. NIFOJ. 32 (1), $117-125$.
Rumiyati, AP James; Jayasema, V (2012). Effect of Germination on the Nutritional and Protein profile of Australian Sweet Lupin (Lupinus Angustifolius L.) Food and Nutrition Sci. 3: $621-626$

Shipard, I (2005). How can I Grow and use Sprouts as Living Food? Stewart Publishing, Australia: Pp $10-20$.

Skulinova, M Kadlec, P Kaasova, J Dostalora, J Zatopkova, M; Mosnedl, V; Hrachovivova, J (2002). Microwave Treatment and Drying of Germinated Pea. Zech. J. Food Sci. 20, 23 - 30.

Srilakshmi, (2008). Nutrition Science. New Age International (P) Limited Publishers, New Delhi, Pp. $108-125$.

Uche, SN; Charity, UN; Abbas, O; Aliyu, M; Francis, CB; Oche, O (2014). Proximate, antinutrients and mineral composition of raw and processed (boiled and roasted) Sphenostylis sternocarpa seeds from Southern Kaduna North-West Nigeria. ISRN. Nutrition.

Udebibie, ABI (1997). Jackbean (Canavalia ensiformis) Meal in Poultry Diets. In Sustainable Rural Poultry Production in Africa. E.B. Sonaiya (ed.), pp. 97-107 